\title{
GLOSA DO WYROKU SĄDU NAJWYŻSZEGO Z DNIA 3 GRUDNIA 2014 R., II KK 219/14
}

\begin{abstract}
Streszczenie. Artykuł stanowi glosę aprobującą do wyroku Sądu Najwyższego z dnia 3 grudnia 2014 r., II KK 219/14. W szczególności zwrócono uwagę na płynącą z tego wyroku konieczność ustalenia rzeczywistego wpływu środka odurzającego na sprawność psychomotoryczną kierowcy w razie popełnienia przestępstwa przeciwko bezpieczeństwu ruchu pod wpływem tego środka odurzającego. Autorzy proponują użycie testów służących do oceny upośledzenia psychomotorycznego u kierowców podejrzanych o użycie substancji działających podobnie do alkoholu.
\end{abstract}

Słowa kluczowe: środki odurzające, środki działające podobnie do alkoholu, zdolność psychomotoryczna, narkotestery.

Materiał dowodowy, na który składają się wylącznie badania narkotesterem oraz wyjaśnienia oskarżonego, podającego że kilka godzin przed zatrzymaniem palił marihuanę, nie uzasadnia ustalenia, że oskarżony znajdowal się „pod wypływem” środka odurzającego, w rozumieniu art. 178a $§ 1$ ustawy z 6.6.1997 r. - Kodeks karny. (Dz. U. Nr 88, poz. 553 ze zm.), a zatem, że substancja odurzająca znajdująca się w jego organizmie miała wpływ na jego zachowanie w sposób zbliżony do znajdowania się w stanie nietrzeźwości. Okoliczności sprawy tym samym budzą poważne wątpliwości co do realizacji przez oskarżonego znamion czynu $z$ art. 178a $§ 1$ KarKod, co nie pozwala uwzględnić wniosku w trybie z art. 387 ustawy z 6.6.1997 - Kodeks postępowania karnego (Dz. U. Nr 89, poz. 555 ze zm.).

Problemy, które poruszył Sąd Najwyższy w wyroku z 3.12.2014 r. (II KK 219/14, KZS 2015. Nr 3, poz. 54), od wielu lat wywołują szereg kontrowersji. Pierwszą dyskusyjną kwestią jest pojęcie środka odurzającego w rozumieniu art. 178a § 1 KarKod. Jak wskazał Sąd Najwyższy w uchw. z 27.2.2007 r. (I KZP 36/06, OSNKW 2007, Nr 3, poz. 21) (Glosy: Stefański 2007, 130-135; Małek 2007, 96-100; Łucarz, Muszyńska 2008b, 122-130; Wojtanowska 2008, 141-153;

* Uniwersytet Łódzki, Wydział Prawa i Administracji, Katedra Postępowania Karnego i Kryminalistyki, Zakład Postępowania Karnego, magdalencja01@outlook.com.

** Uniwersytet Łódzki, Wydział Prawa i Administracji, Katedra Postępowania Karnego i Kryminalistyki, Zakład Kryminalistyki, zbigniew.wardak@gmail.com. 
Olszewski 2008, 154-159; Dąbrowski 2009, 128-133; Huminiak 2007, 5-12; Kachel 2008, 139-142), podobnie jak wcześniej w uchw. SN (7) z 15.2.1973 r. (VI KZP 78/72, OSP 1974, Nr 7-8, poz. 178) (Glosy: Hanausek 1974, 351-354; Redo 1976, 175-179; Hołda 1973, 43-46; zob. też Stefański 1999, 18-24), pojęcie środka odurzającego w rozumieniu art. 178a $§ 1$ KarKod obejmuje nie tylko środki odurzające wskazane w ustawie o przeciwdziałaniu narkomanii, lecz również inne substancje pochodzenia naturalnego lub syntetycznego, działające na ośrodkowy układ nerwowy, których użycie powoduje obniżenie sprawności w zakresie kierowania pojazdem. Problem ten, pomimo wątpliwości zgłaszanych w doktrynie (zob. m.in. powołana glosa A. Olszewskiego; także m.in. Dąbrowska-Kardas, Kardas. 1999, 42.; Krajewski. 2003, 33-35; Sabatowski. 2003, 157-170), należy wobec treści uchwał Sądu Najwyższego uznać za rozstrzygnięty.

Natomiast nadal dyskusyjne są kryteria rozróżnienia „stanu pod wpływem środka odurzającego", o którym mowa m.in. w art. 178a § 1 KarKod od „stanu po użyciu podobnie działającego środka", na jaki wskazuje przepis art. $87 \S 1$ ustawy z 20.5.1971 r. - Kodeks wykroczeń (tekst jedn. Dz. U. z 2015 r., poz. 1094 ze zm.). Jak zauważył Ryszard. A. Stefański (Stefański 2008a, 368-369), w tej sprawie zajmowane są trzy stanowiska. Według pierwszego, stany te są tożsame, a zarówno w jednym, jak i drugim wypadku istotne jest tylko wprowadzenie środka do organizmu, a realny wpływ tego środka na zdolności psychomotoryczne jest prawnie indyferentny. Brak znamion ilościowych daje podstawę do twierdzenia, że ustawodawca, konstruując znamiona występku z art. 178a § 1 KarKod, bądź zapomniał, że takie samo zachowanie - w zakresie użycia środka odurzającego jest już zabronione przez art. $87 \S 1$ lub 2 WykrKod, bądź popełnił błąd (Skowron 2004, 17-18; Skowron 2006, 24; Skowron 2007, 32-38; Skowron 2012a, 5-12; Skowron 2012b.; Skowron 2012c; Skowron 2014a, 25-31; Skowron 2014b, 20-26). Zgodnie $\mathrm{z}$ drugim $\mathrm{z}$ wyrażanych $\mathrm{w}$ doktrynie stanowisk różnica ma charakter jakościowy, a nie ilościowy (Marcinkowski 2002, 41), a „stan po użyciu środka działającego podobnie do alkoholu" zachodzi w razie wprowadzenia do organizmu nieaktywnego metabolitu ${ }^{1}$, a ujawnienie aktywnej formy ${ }^{2}$ niezależnie od wyniku badania lekarskiego i oznaczonego stężenia we krwi (Korczyńska et al. 2011, 42) związków działających podobnie do alkoholu potwierdzałoby „stan pod wpływem środka odurzającego" (Kała 2004, 48; Kała et al. 2005, 141)3. Według trzeciego poglądu różnica między tymi stanami ma charakter ilościowy; „stan pod wpływem środka odurzającego" różni się od „stanu po użyciu środka działającego podobnie do alkoholu" stopniem intoksykacji, a różnica ta sprowadza się do

\footnotetext{
${ }^{1}$ Np. 11-nor-9-karboksy- $\Delta^{9}$-tetrahydrokannabiol (THCCOOH).

${ }^{2}$ Np. $\Delta^{9}$-tetrahydrokannabiol $\left(\Delta^{9}\right.$-THC) albo aktywny metabolit 11 -hydroksy- $\Delta 9$-tetrahydrokannabiol (11-OH-THC).

${ }^{3}$ Zob. podobnie m.in. Huminiak (2005, 13-14), który zmienił swoje wcześniejsze stanowisko, zawarte m.in. w: Huminiak 2004, 14.
} 
stopnia działania na organizm. Ten zaś zależy od rodzaju i ilości wprowadzonego środka (zob. m. in. Stefański 1999, 18-19). W glosowanym judykacie Sąd Najwyższy stwierdził, że wobec braku zdefiniowania stanu „pod wpływem środka odurzającego" oraz stanu „po użyciu środka podobnie działającego do alkoholu”, którym posługuje się art. $87 \S 1$ WykrKod. - sąd rozpoznając sprawę o przestępstwo przeciwko bezpieczeństwu w komunikacji popełnione pod wpływem środka odurzającego, a więc także o przestępstwo z art. 178a § 1 KarKod, każdorazowo musi ustalić, czy środek ten miał realny wpływ na sprawność psychomotoryczną kierującego pojazdem w stopniu podobnym do znajdowania się pod wpływem alkoholu. Teza ta stanowi powtórzenie tez formułowanych już wcześniej w orzeczeniach Sądu Najwyższego, tj. wyr. z 7.2.2007 r. (V KK 128/06, KZS 2007 Nr 6, poz. 39) (Glosy: Stefański 2008b, 152-158; Skowron 2012b), post. z 31.5.2011 r. (V KK 398/10, Prok. i Pr. - dodatek „Orzecznictwo” 2011, Nr 12, poz. 4) (Glosa: Skowron 2012c) oraz z 4.10.2013 r. (IV KK 136/13, KZS $2014 \mathrm{Nr} 1$, poz. 2) (Glosy: Stefański 2014, 644-658; Joachimiak 2014, 18-23). Sąd Najwyższy tym samym konsekwentnie przychyla się do trzeciego z powołanych stanowisk.

Podkreślić należy, że jak słusznie wskazał Sąd Najwyższy w uzasadnieniu powoływanej uchw. z 27.2.2007 r. (I KZP 36/06), rodzajowym przedmiotem ochrony występku z art. 178a $\S 1$ KarKod jest bezpieczeństwo w komunikacji, co wskazuje ogólny kierunek wykładni m.in. art. 178a § 1 KarKod. Podobnie wykładnia funkcjonalna tego przepisu prowadzi do wniosku, że chodzi mianowicie o ochronę tego bezpieczeństwa przed zagrożeniem wynikającym z obniżonej sprawności kierowcy, która może polegać na obniżonej zdolności psychomotorycznej (np. wydłużenie czasu reakcji), ale również wynikać z zażycia środka powodującego zmiany przebiegu procesów psychicznych (np. zakłócenie prawidłowości procesu podejmowania bieżących decyzji w trakcie kierowania pojazdem). Ratio legis art. 178a $\S 1$ KarKod polega więc na ochronie bezpieczeństwa ruchu przed zachowaniami kierowców polegającymi na prowadzeniu pojazdów W stanie obniżonej sprawności psychomotorycznej lub w stanie zakłócenia procesów psychicznych. Jak słusznie wskazują przy tym K. Łucarz i A. Muszyńska, intencją ustawodawcy było spenalizowanie użycia substancji podobnych w skutkach do wyżej wymienionych, przy czym podobieństwo to musi dotyczyć nie tyle zdolności do uzależnienia, ile doraźnych efektów wprowadzenia ich do organizmu - w postaci zakłócenia czynności psychomotorycznych, wywołania euforii bądź apatii, omamów oraz innych zaburzeń wzrokowo-słuchowych (Łucarz, Muszyńska 2008a, 101; Łucarz, Muszyńska 2008b, 129). Tym samym dokonując oceny, czy w danym przypadku mamy do czynienia ze „stanem pod wpływem środka odurzającego" czy też „stanem po użyciu środka działającego podobnie do alkoholu", nie możemy tracić z pola widzenia przedmiotu ochrony, tzn. bezpieczeństwa w komunikacji, a zatem penalizowane mogą być jedynie zachowania, które godzą w bezpieczeństwo w ruchu drogowym. Przy zastosowanym m.in. w art. 178a § 1 KarKod pojęciu „stanu pod wpływem środka odurzającego”, nie 
można przyjąć, że warunkiem wystarczającym jest stwierdzenie substancji aktywnej lub jej aktywnego metabolitu, bowiem wprost z przepisu wynika, iż środek odurzający ma mieć wpływ na funkcjonowanie kierowcy, stąd też nie jest wystarczająca jakakolwiek ilość substancji aktywnej lub jej aktywnego metabolitu (wyr. SN z 7.2.2007 r., V KK 128/06). Podobnie w przypadku art. $87 \S 1$ WykrKod nie można przyjąć, że wystarczające jest stwierdzenie w badaniach jedynie nieaktywnych metabolitów ${ }^{4}$, które nie mają żadnego negatywnego oddziaływania na zdolności psychomotoryczne kierowców (Skowron 2006, 22) i co do zasady nie mogą przekształcić się w aktywny metabolit, co nie daje się pogodzić z koniecznością negatywnego wartościowania takiego zachowania i podważa występowanie elementu materialnego już na poziomie abstrakcyjnego opisu (Pawlik 2013, 53; Pawlik 2014, 61). Stanowisko, że „stan po użyciu środka działającego podobnie do alkoholu" zachodzi w razie wprowadzenia do organizmu nieaktywnego metabolitu, a ujawnienie aktywnej formy związków działających podobnie do alkoholu potwierdzałoby „stan pod wpływem środka odurzającego”, stanowi drogę na skróty, przybierając postać wykładni contra legem, z powodu nieuwzględnienia dyrektyw ustawodawcy, który używając sformułowań ,ppod wpływem” i „po użyciu” wskazuje na podstawową rolę, jaką te środki mają mieć dla zdolności psychomotorycznych kierującego (Nowak 2013, 22). Podobnie trudno zaakceptować stwierdzenie, że ustawodawca popełnił błąd, a realny wpływ tego środka na zdolności psychomotoryczne jest prawnie indyferentny. Jest oczywiste, że ustawodawca popełnia błędy, jednakże na użytek wykładni interpretator jest zobligowany przyjąć fikcję racjonalnego ustawodawcy, bez takiego bowiem założenia nie można wpierw wyłożyć, a następnie zastosować budzących wątpliwości przepisów.

Zgodnie z rozporządzeniem Ministra Zdrowia z dnia 16 lipca 2014 r. w sprawie wykazu środków działających podobnie do alkoholu oraz warunków i sposobu przeprowadzania badań na ich obecność w organizmie (Dz. U. z 2014 r., poz. 948.), w celu ustalenia w organizmie obecności środka działającego podobnie do alkoholu przy użyciu metod niewymagających badania laboratoryjnego stosuje się nieinwazyjne pobranie próbek śliny i umieszczenie ich w urządzeniu do oznaczania metodą immunologiczną środków działających podobnie do alkoholu, zgodnie z instrukcją obsługi tego urządzenia (§ 2 ust. 1 WykŚrRozp), przy czym do tych próbek nie wolno dodawać jakichkolwiek substancji, poza znajdującymi się w zestawie urządzenia do oznaczania metodą immunologiczną środków działających podobnie do alkoholu (§ 2 ust. 2 WykŚrRozp). Narkotestery służą do bezpośredniej szybkiej kontroli osób podejrzanych na miejscu zdarzenia metodami nielaboratoryjnymi, są przeznaczone do rutynowej szybkiej analizy skryningowej najczęściej notowanych związków psychoaktywnych (amfetamin, kannabioli, opiatów, kokainy, benzodiazepin) na miejscu zdarzenia, przy czym

\footnotetext{
${ }^{4}$ Jakim jest np. THCCOOH.
} 
zaleca się, aby jednocześnie sporządzić protokół obserwacji zachowań osoby badanej, stanowiący integralną część badań nielaboratoryjnych (Wachowiak 2005, 155). Z przebiegu tych badań sporządza się protokół, który zawiera m.in. opis objawów i okoliczności uzasadniających podejrzenie użycia środka działającego podobnie do alkoholu ( $\$ 6$ pkt 4 WykŚrRozp). Końcowy pozytywny wynik raportu wymaga zawsze przeprowadzenia dodatkowego badania potwierdzającego obecność związku psychoaktywnego we krwi. W 74-92\% przypadków wyniki badań testowych znajdują potwierdzenie w późniejszych badaniach chemicznych krwi (Wachowiak 2005, 155). Wyniki uzyskane urządzeniami wykorzystującymi reakcje immunologiczne (nazywane analizatorami śliny lub narkotesterami) uznaje się w toksykologii sądowej za wstępnie dodatnie, co oznacza, że muszą być potwierdzone metodą działającą na innej zasadzie - najlepiej chromatograficzną (Kała 2004, 49). Należy stwierdzić, że Sąd Najwyższy w glosowanym wyroku słusznie przyjął, iż w przypadku dysponowania w materiale dowodowym jedynie pozytywnym wynikiem badania narkotesterem Rapid Stat, nie ma podstaw do ustaleń, iż skazany znajdował się pod wpływem środka odurzającego. Wynik dodatni uzyskany za pomocą analizatora śliny jest sumą związków aktywnych i nieaktywnych (Kała 2004, 58), bez określenia ich ilości, co nie pozwala na jednoznaczne stwierdzenie, że osoba badana pozostawała pod wpływem środka odurzającego. Przy paleniu konopi bądź wciąganiu kokainy przez nos, odpowiednio kannabiole i kokaina mogą zalegać w przedsionku jamy ustnej (przy policzkach), ponadto niektóre barwne substancje zalegające w jamie ustnej, np. tytoń lub kakao, mogą także zafałszować wynik narkotestera i skutkować wynikiem pozytywnym (Kała 2004, 63; zob. też Chudzikiewicz et al. 2005, 174). Trudno także uznać w przedmiotowej sprawie, wobec braku innych dowodów, iż wyjaśnienia oskarżonego potwierdziły, że znajdował się on ,pod wpływem środka odurzającego”, bowiem dowodziły one jedynie, iż kilka godzin przed zatrzymaniem palił marihuanę, co samo w sobie nie potwierdza tego stanu. Jak zauważył A. Skowron, wskutek opracowania przez Biuro Prewencji Ruchu Drogowego Komendy Głównej Policji sposobu postępowania, w przypadku pozytywnego wyniku badania za pomocą jednego z dopuszczonych do użytku narkotesterów, w najbliższej placówce zdrowia od kierującego pobierana jest próbka krwi (lub moczu), która jest następnie przesyłana do dalszego badania, co spowoduje, iż nie dojdzie do sytuacji, że jakaś osoba zostanie oskarżona o wykroczenie z art. 87 WykrKod (Skowron 2007, 37). Przypadek, którego dotyczy glosowany wyrok, pokazuje, że w oparciu o badanie narkotesterem kierowca został nie tylko oskarżony, ale prawomocnie skazany i to nie tylko o wykroczenie z art. 87 WykrKod, ale o występek z art. 178a KarKod. Ponadto zgodnie z $\S 10$ zd. 2 i $§ 11$ zarządzenia Komendanta Głównego Policji Nr 496 z 25.5.2004 r. w sprawie badań na zawartość w organizmie alkoholu lub środka działającego podobnie do alkoholu (Dz. Urz. KGP. Nr 9, poz. 40 z późn. $\mathrm{zm}$.), w przypadku utwierdzenia się policjanta w podejrzeniu, że podejrzany znajduje się w stanie po użyciu środków działających podobnie do alkoholu, a jego 
badanie urządzeniem elektronicznym nie wykazało co najmniej stanu po użyciu alkoholu, kierującego należy poddać badaniu śliny. Natomiast badania krwi lub moczu w celu ustalenia w organizmie obecności środka działającego podobnie do alkoholu przeprowadza się jedynie: $w$ razie uczestniczenia kierującego pojazdem w wypadku drogowym, w którym jest zabity, na żądanie osoby, która była poddana badaniu śliny, jeżeli stan badanego uniemożliwia przeprowadzenie badania śliny, jeżeli badany odmawia poddania się badaniu stanu trzeźwości urządzeniami elektronicznymi, w razie braku możliwości poddania kierującego pojazdem badaniom alkomatem oraz narkotesterem, a jednocześnie w wyniku obserwacji jego zachowania zachodzi uzasadnione podejrzenie, że znajduje się on w stanie po użyciu środków działających podobnie do alkoholu. Tym samym wytyczne obowiązujące policjantów nie gwarantują prawidłowości procedury, że w przypadku podejrzenia kierowania pojazdem po użyciu środków działających podobnie do alkoholu lub pod wpływem środków odurzających i pozytywnego wyniku z badania narkotesterem zostaną przeprowadzone badania krwi i moczu. Należy także zauważyć, iż w związku z faktem, że narkotestery wykrywają tylko grupy niektórych substancji, wynik badania narkotesterem może być negatywny, więc powinno być przeprowadzone badanie krwi lub moczu celem stwierdzenia środków odurzających.

Wpływ środka odurzającego na zachowanie kierowcy może być wykazany przez stwierdzenie obecności aktywnej formy takiego środka w organizmie kierowcy - we krwi (Kała 2004, 49), w okresie jej najwyższej aktywności farmakologicznej (Wachowiak 2007, 155). Czas pozostawania każdego ksenobiotyku w organizmie jest determinowany jego zróżnicowanymi parametrami farmakokinetycznymi, które powinny stanowić pomocniczą wartość interpretacyjną, ponadto podobne zależności interpretacyjne dotyczą alternatywnych materiałów, tj. śliny i moczu (Wachowiak 2007, 155). Badanie krwi na obecność substancji odurzających stanowi zadanie znacznie trudniejsze od oznaczenia etanolu, gdyż stężenia substancji czynnych, tj. narkotyków lub leków we krwi, są średnio o 10 000-1 000000 razy niższe od stężeń etanolu (Sybirska, Szczepański, Kulikowska 1999, 75).

Należy przy tym zauważyć, że wykrycie w organizmie postaci aktywnej środka odurzającego nie oznacza jeszcze, iż zażywanie tego środka wywiera wpływ na sprawność psychomotoryczną, czy też że wywołuje on zakłócenie czynności psychicznych. Nie ma ponadto przynajmniej prostego przełożenia między wyznaczonym stężeniem $\Delta^{9}$-THC (a także innych substancji) a znamieniem „,bycia pod wpływem środka odurzającego" (Girdwoyń 2012). Jak zauważył R. Wachowiak w przypadku $\Delta^{9}$-THC (tj. substancji czynnej zawartej w marihuanie i haszyszu), stwierdzając obecność czynnego związku we krwi w stężeniu powyżej $2.0 \mathrm{ng} / \mathrm{ml}$, wskazujemy na stan pod wpływem, względnie obecność czynnego związku we krwi w niskim stężeniu (poniżej $2.0 \mathrm{ng} / \mathrm{ml}$ ) z zauważalnymi objawami odnotowanymi w protokole pobrania krwi - stan pod wpływem. W przypadku obecności 
czynnego związku we krwi w niskim stężeniu (poniżej $2.0 \mathrm{ng} / \mathrm{ml}$ ), bez wskazania zauważalnych objawów, trudno jednoznacznie się wypowiedzieć, czy badany znajdował się pod wpływem czy po użyciu takiego środka, bowiem zażyty środek odurzający może w tym przypadku oddziaływać na sprawność psychofizyczną kierowcy, ale nie wiadomo, czy na pewno nastąpiło takie oddziaływanie. Przy stężeniu $\Delta^{9}$-THC wyższym aniżeli $10 \mathrm{ng} / \mathrm{ml}$ występuje niekwestionowane zakłócenie zdolności psychomotorycznej człowieka. Natomiast dla zakresów niższych stężeń $\Delta^{9}$-THC we krwi, np. poniżej $10 \mathrm{ng} / \mathrm{ml}$, a w szczególności poniżej $5 \mathrm{ng} / \mathrm{ml}$, występuje element niepewności interpretacyjnej (Wachowiak 2008, 6). Do niedawna powszechnie wskazywano, że złożoność przemian, jakim ulegają opiaty, amfetaminy, kokaina i tetrahydrokannabiole w organizmie ludzkim, uzależnienia, jakie wywołują oraz ich konsekwencje w postaci zjawiska tolerancji i objawów abstynencji, uniemożliwiają wyznaczenie wartości granicznego stężenia lub nawet zakresu stężeń granicznych dla poszczególnych aktywnych związków tych środków we krwi, nie jest zatem możliwe wprowadzenie tzw. wartości progowych, jak to ma miejsce w przypadku alkoholu (Kała 2004, 62). Jednakże środowisko toksykologów sądowych na konferencji „Środki podobnie działające do alkoholu - interpretacja wyników badań krwi kierowców dla potrzeb sądowych", która odbyła się w Krakowie w dniach 28-29 listopada 2012 r., zaproponowało progi stężeń odróżniające stan ,pod wpływem środka odurzającego" od stanu „po użyciu tego środka” dla 5 grup substancji. Propozycję tę potwierdzono podczas XXX Konferencji Toksykologów Sądowych zorganizowanej w maju 2013 r. w Augustowie. Zaproponowane progi kształtują się następująco: dla $\Delta^{9}$-THC: stan po użyciu $-1^{5}-2,5 \mathrm{ng} / \mathrm{ml}$, stan pod wpływem - $>2,5 \mathrm{ng} / \mathrm{ml}$; dla amfetaminy i pochodnych: stan po użyciu $-25^{6}-50 \mathrm{ng} / \mathrm{ml}$, stan pod wpływem $->50 \mathrm{ng} / \mathrm{ml}$; dla kokainy: stan po użyciu $-10^{7}-20 \mathrm{ng} / \mathrm{ml}$, stan pod wpływem $->20 \mathrm{ng} / \mathrm{ml}$; dla benzoiloekgoniny: stan po użyciu $->100^{8} \mathrm{ng} / \mathrm{ml}$, stan pod wpływem: - nie ustalono; dla morfiny: stan po użyciu $-10^{9}-25 \mathrm{ng} / \mathrm{ml}$, stan pod wpływem - > $25 \mathrm{ng} /$ ml (Ćwiklińska et al. 2015, 81; zob. też Stefański 2014, 658).

Sam wynik badania moczu nie upoważnia do przyjęcia, że badany znajdował się pod wpływem czy po użyciu środka odurzającego, bowiem wiele środków wydala się z moczem w postaci nieaktywnych metabolitów długo po ustąpieniu działania tych środków na organizm (Kała 2004, 49). W przypadku gdy badania laboratoryjne wykazały wyłącznie obecność metabolitu związku psychoaktywnego w moczu przy całkowitej nieobecności we krwi, występują szczególne ogra-

${ }^{5} 1 \mathrm{ng} / \mathrm{ml}$ stanowi granicę oznaczalności dla $\Delta^{9}$-THC zgodnie z $\S 3$ ust. 4 pkt 4 WykŚrRozp.

${ }^{6} 25 \mathrm{ng} / \mathrm{ml}$ stanowi granicę oznaczalności dla amfetaminy i jej analogów, w tym MDMA zgodnie z $§ 3$ ust. 4 pkt 2 WykŚrRozp.

$710 \mathrm{ng} / \mathrm{ml}$ stanowi granicę oznaczalności dla kokainy zgodnie z § 3 ust. 4 pkt 3 WykŚrRozp.

${ }_{8} 100 \mathrm{ng} / \mathrm{ml}$ stanowi dwukrotność granicy oznaczalności dla benzoiloekgoniny zgodnie z $§ 3$ ust. 4 pkt 3 WykŚrRozp.

$910 \mathrm{ng} / \mathrm{ml}$ stanowi granicę oznaczalności dla morfiny zgodnie z $§ 3$ ust. 4 pkt 1 WykŚrRozp 
niczenia interpretacyjne, np. zmiany $\Delta^{9}$-THC podczas przyjmowania marihuany, którego maksymalny poziom we krwi po jednorazowej ekspozycji utrzymywany jest przez ok. 2 godzin, a obecność głównego metabolitu, tj. THCCOOH w moczu można potwierdzić przez okres kilku dni (Wachowiak 2005, 155). Jednoznacznym dowodem naruszenia obowiązujących przepisów ruchu drogowego przez kierowcę jest potwierdzenie przyjęcia przez niego środka psychoaktywnego poprzez badanie laboratoryjne krwi, śliny oraz moczu, przy wyznaczonych eksperymentalnie parametrach farmakokinetycznych środka psychoaktywnego. Jedynie to pozwoli uzyskać obiektywny obraz stopnia zaburzeń psychoaktywnych, wyrażający się w ustalonych wartościach stężeń w płynach ustrojowych (tamże). Analiza toksykologiczna dwóch rodzajów materiału biologicznego (krwi i moczu) daje podstawy do szerszej interpretacji wyników w odniesieniu do czasu przyjęcia danego środka odurzającego (Kała 2004, 49). Przydatne mogą być także badania śliny, które to badanie może służyć jako wskaźnik diagnostyczny do orzekania o niedawnym przyjęciu marihuany (Kochanowski, Kała 2005, 186). Inne metody, jak np. badanie włosów, są raczej nieprzydatne do stwierdzenia stanu, w jakim znajdował się kierujący podczas kierowania pojazdem, natomiast mogą być przydatne w profilaktyce zjawiska, bowiem mogą i bywają wykorzystywane (Niemcy, Austria) w celach kontroli (badań) kierowców przed wydaniem lub zwrotem prawa jazdy, stanowiąc materiał komplementarny zarówno dla płynów ustrojowych, takich jak krew, mocz oraz ślina, ale również pod względem interpretacyjnym dla badania lekarskiego (Lechowicz, Bunker 2005, 157-165).

Należy przy tym zauważyć, że jak wynika z przeprowadzanych badań, często w czasie analiz wykrywa się więcej niż jedną substancję (zob. m.in. Ćwiklińska et al. 2015, 82 $2^{10}$; Korczyńska et al. 2011, $37^{11}$ ). Oddziaływanie na zdolności psychomotoryczne kilku substancji nie jest do końca zbadane i może upośledzać w większym stopniu ośrodkowy układ nerwowy, niż mogłoby to wynikać z danych stężeń pojedynczego środka we krwi (zob. m.in. Pawlik 2013, 50). Podkreślenia przy tym wymaga, że działanie np. $\Delta^{9}$-THC może utrzymywać się dłużej niż występuje mierzalne jego stężenie we krwi (Kała 2004, 54). Stąd także z tego względu potrzebne wydaje się badanie zachowania sprawcy i próba ustalenia wpływu na zachowanie przyjętego środka odurzającego. Obiektywna diagnoza stanu psychofizycznego osoby podejrzanej o kierowanie pojazdem w stanie pod wpływem środka odurzającego winna być zatem oparta na kompleksowej ocenie wyniku badania przedlaboratoryjnego (śliny), ustaleń i obserwacji dokonanych przez policję i innych świadków zdarzenia, wyniku badania laboratoryjnego (krwi) oraz ustalonych zachowań i objawów działania związku psychoaktywnego odnotowanych przez lekarza w protokole bezpośrednio przed pobraniem do analizy próbki krwi (Korczyńska et al. 2011, 36; także Chowaniec 2000, 159-164).

\footnotetext{
${ }^{10} \mathrm{~W} 14$ przypadkach (27\% spraw) wykryto więcej niż jedną substancję.

${ }^{11}$ W 50 przypadkach (34\% spraw) wykryto więcej niż jedną substancję.
} 
Słusznie zatem zauważył L. K. Paprzycki, że nigdy nie można zaniechać dwóch czynności, tj. po pierwsze pobrania próbki krwi, zbadania zawartości alkoholu i środków odurzających, przeprowadzenia dowodu z opinii biegłego co do rodzaju środka, stężenia we krwi oraz typowego następstwa takiego stężenia, i po drugie udokumentowanie, poprzez utrwalenie obrazu i dźwięku, a także uzyskanie zeznań świadków co do zachowania kierowcy w czasie prowadzenia pojazdu i po zatrzymaniu. Tylko tak zgromadzone dowody pozwolą ustalić, że kierowca nie tylko użył środka odurzającego, ale także odróżnić stan „po użyciu” od stanu „pod wpływem” środka odurzającego (Paprzycki 2012, 29).

W przedmiotowej sprawie Sąd Najwyższy przyjął, że konieczne jest dokonywanie ustaleń dowodowych w zakresie zachowania się osoby badanej w chwili zdarzenia, często połączone z ekspertyzą biegłych ${ }^{12}$. W orzecznictwie wskazuje się, że dla ustalenia, czy w danym wypadku zachodzi stan „pod wpływem środka odurzającego" czy też „po użyciu takiego środka”, pomocne być mogą inne dowody, np. zeznania świadków obrazujące zachowanie sprawcy tempore criminis (wyr. SN z 7.2.2007 r., V KK 128/06). Wskazuje się także, że przeprowadzając ocenę zaburzeń zdolności psychomotorycznych, w przypadku dysponowania tylko badaniem krwi, wykazującym stan stężenia środka odurzającego zbliżony do stężenia progowego, należy odwołać się do dowodów opisujących wygląd sprawcy, funkcjonowanie określonych jego organów, opisanych przez lekarza obecnego podczas pobierania krwi od oskarżonego, pozwalających na ustalenie sposobu jego zachowania (post. z 31.5.2011 r., V KK 398/10). Jednakże nie można przyjąć, że takie środki dowodowe, jak zeznania świadków opisujących zachowanie sprawcy, mogą zastąpić analizę krwi, której znaczenie w takich sprawach jest zasadnicze. W przypadku znacznego odurzenia sprawcy oczywiście jego objawy mogą być łatwo zauważalne dla świadków, jednakże w przypadku mniejszego jego nasilenia takie objawy są bardzo trudne do zaobserwowania i przypisania ich do stanu odurzenia. Ponadto w przeprowadzonych badaniach aktowych stwierdzono, iż w grupie 52 badanych spraw jedynie w 3 przesłuchano świadków zdarzenia na okoliczność zachowania się kierowcy (Ćwiklińska et al. 2015, 77). Problematyczne bywa także oparcie się na wstępnych badaniach lekarskich, bowiem w przeprowadzonych badaniach nie stwierdzono istotnej zależności między wynikami badań toksykologicznych i elementami badania lekarskiego zawartymi w protokołach badania krwi, jak wygląd skóry, mowa, tętno, źrenice, reakcja źrenic na światło, chód, podnoszenie przedmiotów z ziemi, próba Romberga, próba palec-nos oraz orientacja co do miejsca, czasu i otoczenia, a stwierdzono istotną zależność jedynie z nastrojem (Wolski et al. 2013, 148). W innych badaniach, w przypadku kannabioli (w 43\% badanych przypadków) stwierdzono zmianę szerokości źrenic, ich zwolnioną reakcję na światło, zaczerwienienie skóry twarzy,

${ }^{12}$ Sąd Najwyższy powtórzył to za wyrokiem Sądu Najwyższego z dnia 4 października 2013 r., sygn. IV KK 136/13. 
zmiany w zachowaniu (wesołkowatość, gadatliwość) oraz zaburzenia orientacji. W przypadku amfetaminy odchyleniami obserwowanymi jedynie u $29 \%$ badanych były rozszerzone źrenice i zaburzenia równowagi (niepewny chód, niepewne podnoszenie przedmiotów z ziemi), wreszcie w grupie, w której stwierdzono więcej niż jedną substancję psychoaktywną, w połowie przypadków obserwowano objawy upośledzenia funkcji układu nerwowego (Korczyńska et al. 2011, 39). Na podstawie niewielkiej ilości prezentowanych przypadków - dotyczących osób, u których stwierdzono $\Delta^{9}$-THC lub amfetaminę - podobnie wywnioskowano, że brakuje korelacji pomiędzy oznaczonym stężeniem substancji psychoaktywnej we krwi a obserwowanymi przez lekarza objawami jej działania, zaś ostateczne rozpoznanie przez lekarza stanu ,pod wpływem substancji odurzających lub psychotropowych" często nie wynikało z istniejących, stwierdzonych w badaniu lekarskim objawów, lecz było formułowane w oparciu o uzyskany wywiad lub sugestie policji (Korczyńska et al. 2011, 40). Należy jednak zauważyć, że pobranie krwi następuje najczęściej po kilku godzinach od zdarzenia (Ćwiklińska et al. 2015, 81-82) ${ }^{13}$, a czas opóźnienia mógł wpłynąć na obserwowane reakcje. Należy dążyć do tego, aby pobranie krwi i moczu następowało możliwie jak najszybciej od zdarzenia. Ponadto, negatywnie należy ocenić fakt, iż co prawda w protokole zarówno badania narkotesterem, jak i pobrania krwi i moczu, należy dokonać opisu objawów i okoliczności uzasadniających podejrzenie użycia środka działającego podobnie do alkoholu (§ 6 pkt 4 WykŚrRozp), to jeżeli w wyniku obserwacji zachowania kierującego pojazdem zachodzi podejrzenie, że znajduje się on w stanie po użyciu środków działających podobnie do alkoholu, a jego badanie urządzeniem elektronicznym nie wykazało co najmniej stanu po użyciu alkoholu, kierującego należy poddać testom psychofizycznym, polegającym m.in. na sprawdzeniu reakcji źrenic, próbie „palec-nos” lub ,palec-palec”(§ 10 BadZawZarz), jednakże nie jest to $\mathrm{w}$ jakikolwiek sposób zestandaryzowane. Przepisy nie zawierają przy tym dokładnych kryteriów zabezpieczenia do badań chemiczno-toksykologicznych materiału biologicznego (Wiergowski et al. 2012, 187).

W wielu krajach prowadzi się badania i wykorzystuje się w praktyce zestawy testów psychofizycznych przeprowadzanych przed pobraniem próbek do badań toksykologicznych, np. w Stanach Zjednoczonych używany jest zestaw testów, tzw. standaryzowany drogowy test trzeźwości (Standardized Field Sobriety Test - SFST), a zestaw testów używany jest w ramach programu oceny i klasyfikacji leków (The Drug Evaluation and Classification Programme - DEC). W Wielkiej Brytanii prowadzone są doświadczenia nad skutecznością drogowego testu niezdolności (Field Impairment Test - FIT), zaś w Finlandii kliniczny test dla osób

${ }^{13}$ Wskazują, w oparciu o przeprowadzone badania, że z wyjątkiem 1 przypadku (kiedy moment pobrania był odroczony aż o ponad 16 godzin od zatrzymania), czas ten wynosił poniżej 4 godzin (średnio 2 godziny i 14 minut), najkrótszy czas to 30 minut, natomiast w 5 sprawach nie udało się ustalić czasu, jaki minął pomiędzy zdarzeniem a pobraniem krwi do badań. 
nietrzeźwych (Finland's Clinical Test for Drunkenness - CTD) (Engelgardt, Pufal, Śliwka 2006, 375). Nawet dzięki najprostszemu zestawowi testów, tj. SFST, uzyskuje się 44\% i więcej poprawnych rozpoznań, czyli prawie dwa razy więcej niż dzięki stosowanemu aktualnie w Polsce badaniu lekarskiemu (Engelgardt, Pufal, Śliwka 2006, 377). Aby uczynić zadość wymaganiu, iż należy każdorazowo ustalić, czy środek odurzający miał realny wpływ na sprawność psychomotoryczną kierującego pojazdem, należałoby zarówno na miejscu zdarzenia, jak i przy pobraniu krwi, stosować opracowane w tym celu zestandaryzowane testy, które pomogłyby ustalić realny wpływ środka odurzającego na zdolność do kierowania pojazdem. Zaletą wykonywania badania na miejscu zdarzenia byłoby wykonywanie ich możliwie jak najbliżej czasowo wobec samego zdarzenia, a badania lekarskie mogłyby w sposób dokładniejszy diagnozować objawy. Zestandaryzowanie badań natomiast w sposób znaczny ułatwiałoby interpretację wyników. Ustalenia dowodowe płynące $\mathrm{z}$ takich badań, opisanych precyzyjnie w protokole, mogłyby mieć większe znaczenie przy orzekaniu i stanowić istotne uzupełnienie badań z krwi. Ciekawa jest w tym zakresie propozycja wysunięta przez M. Wiergowskiego, Z. Jankowskiego, E. Tomczaka, J. Sein Ananda, R. Ziółkowskiego i J. Staniszewskiego dotycząca schematu postępowania z osobą podejrzaną o przyjęcie środka odurzającego, opisu objawów i okoliczności oraz dodatkowych testów, mających stanowić załącznik do protokołu badania śliny, krwi lub moczu (Wiergowski et al. 2012, 192-195).

Pewnym problemem jest ograniczenie płynące z art. $74 \S 1$ PostKarKod, stanowiącego, iż oskarżony (także podejrzany i osoba podejrzana) nie ma obowiązku dowodzenia swej niewinności, ani obowiązku dostarczania dowodów na swoją niekorzyść. Z art. 74 § 2 pkt 1 PostKarKod. wynika że oskarżony jest jednak obowiązany poddać się oględzinom zewnętrznym ciała oraz innym badaniom niepołączonym z naruszeniem integralności cielesnej. Takie próby, jak wyżej pokrótce zaprezentowane, mieszczą się w tym wyłączeniu, przy czym z przepisu tego wynika obowiązek jedynie ,poddania się” badaniom, co oznacza, że nie można zmusić oskarżonego do zachowania czynnego w uzyskiwaniu dowodów przeciwko niemu, a obowiązek ,poddania się” badaniom może polegać na znoszeniu pewnych niedogodności związanych z badaniem (zob. m.in. wyr. SN z 21.7.2000 r., II KKN 108/00, Prok. i Pr. 2001, Nr 1. Dodatek Orzecznictwo, poz. 11). Tym samym pełne zastosowanie takich prób mogłoby mieć miejsce jedynie w przypadku, gdy osoba podejrzana współpracowałaby z organami ścigania, natomiast w przeciwnym razie możliwe byłoby wykonanie jedynie części z nich.

Akceptując przy tym tezę, że każdorazowo należy ustalić, czy środek ten miał realny wpływ na sprawność psychomotoryczną kierującego pojazdem, pewne zastrzeżenie budzi ograniczenie do konieczności ustalania sprawności psychomotorycznej. Środki odurzające bowiem, poza depresyjnym działaniem na ośrodkowy układ nerwowy, niejednokrotnie wywołują euforię, bądź apatię, omamy oraz inne zaburzenia wzrokowo-słuchowe, zakłócenie logicznego myślenia, urojenia 
wzrokowe i słuchowe, zaburzenia poczucia czasu lub przestrzeni lub fałszywe poczucie zwiększonej sprawności (Łucarz, Muszyńska 2008a 101; Łucarz, Muszyńska 2008b, 129; Girdwoyń 2012). Błędy kierowców to nie tylko błędy wykonania danego manewru, który jest konsekwencją błędu w odbiorze informacji lub w jej przetworzeniu, a rzeczywisty błąd tkwi w fazie orientacji lub w fazie decyzji (Rok-Błeszyńska 2003, 148). Takie oddziaływania powodujące zmiany przebiegu procesów psychicznych, np. zakłócające prawidłowość procesu podejmowania bieżących decyzji w trakcie kierowania pojazdem, bywają niejednokrotnie groźniejsze w skutkach od zaburzenia sprawności psychomotorycznej, którą akcentuje w glosowanym wyroku Sąd Najwyższy. Stąd też, zwłaszcza w przypadku niektórych pochodnych amfetaminy, czy też środków psychotropowych, należałoby ustalać tego typu wpływ na kierującego pojazdem mechanicznym. Również ta okoliczność powoduje, że zadania, jakie wynikają z orzecznictwa Sądu Najwyższego, konieczne do przyjęcia „stanu pod wpływem środka odurzającego”, są bardzo trudne do zrealizowania. Jednakże te zadania wynikają ze sformułowań ustawowych, a nigdzie nie sformułowano zasady, że ustawodawca ma obowiązek tylko tak definiować znamiona przedmiotowe, aby można je było w dowodowo prosty sposób wykazać (Nowak 2013, 31).

Analizując sprawę, w której zapadł glosowany wyrok, zwraca szczególną uwagę tryb, w jakim zostało podjęte rozstrzygnięcie pierwszoinstancyjne, a mianowicie wydanie wyroku skazującego w trybie art. 387 PostKarKod, tzn. bez przeprowadzenia postępowania dowodowego. Wniosek złożony w tym trybie można uwzględnić, gdy okoliczności popełnienia przestępstwa nie budzą wątpliwości, stwierdzenie zatem jakichkolwiek wątpliwości powinno skutkować nieuwzględnieniem wniosku oskarżonego złożonego w trybie art. $387 \S 1$ PostKarKod i przeprowadzeniem postępowania dowodowego (wyr. SN z 24.10.2007 r., IV KK 333/07, niepubl. i wyr. SN z 13.10.2011 r., IV KK 201/11, Prok. i Pr. 2012, Nr 2. Dodatek Orzecznictwo, poz. 2.). Przy każdym rozpoznawaniu trafności złożonego w trybie art. $387 \S 1$ i 2 PostKarKod wniosku, sąd ma też obowiązek ocenić, czy zarzucany oskarżonemu czyn został prawidłowo zakwalifikowany, czy też zachodzi potrzeba dokonania innej jego oceny prawnej (zob. m.in. wyr. SN z 11.2.2009 r., III KK 245/08, Prok. i Pr. 2009, Nr 6. Dodatek Orzecznictwo, poz. 32). W przedmiotowej sprawie, wobec nieustalenia realnego wpływu na sprawność psychomotoryczną kierującego pojazdem, co jest warunkiem przyjęcia występku z art. 178a § 1 KarKod, brak podstaw do przyjęcia, iż mamy do czynienia z tym występkiem, a nie z wykroczeniem z art. 87 WykrKod. W przypadku wykonania jedynie testu przesiewowego przy użyciu narkotestera nie można przyjąć, że okoliczności popełnienia przestępstwa nie budzą wątpliwości, bowiem wątpliwości, które nie dają się usunąć przy tak zebranym materiale dowodowym i nie zostały usunięte $\mathrm{w}$ postępowaniu dowodowym, należy rozstrzygać, zgodnie z zasadą z art. $5 \S 2$ PostKarKod, na korzyść oskarżonego (zob. podobnie powoływany wyr. z 7.2.2007 r., V KK 128/06). Fakt, że oskarżony 
przyznał się do palenia marihuany na kilka godzin przed prowadzeniem samochodu, przy nieustalonej zawartości we krwi $\Delta^{9}$-THC oraz bez ustalenia, w oparciu o badania laboratoryjne, a także inne środki dowodowe, jaki był wpływ zażytego narkotyku, nie usuwa wątpliwości co do kwalifikacji prawnej czyny jako występku z art. 178a $§ 1$ KarKod, nie zaś wykroczenia z art. 87 WykrKod. Skoro zatem, dla przyjęcia „stanu pod wpływem środka odurzającego" konieczne jest ustalenie zdolności psychomotorycznych kierującego, przy użyciu zarówno metod laboratoryjnych, jak również innych dowodów, to nie można odstąpić od przeprowadzania takich dowodów, z uwagi na konsensualne zakończenie sprawy.

\section{BIBLIOGRAFIA}

Chowaniec, Czesław. 2000. „Badania nad obecnością leków i środków odurzających w organizmie uczestników ruchu drogowego". Archiwum Medycyny Sąowej i Kryminologii (Suplement) 50: 159-164. http://www.amsik.pl/index.php?option=com_content\&task=view\&id=105 [dostęp 30.10. 2015].

Chudzikiewicz, Ewa, Piotr Adamowicz, Maria Kała, Wojciech Lechowicz, Ewa Pufal, Marzena Sykutera, Karol Śliwka. 2005. "Possibilities of using saliva for testing drivers for estazolam, doxepin and promazine. Możliwości wykorzystania śliny w badaniach kierowców na obecność estazolamu, doksepiny i promazyny”. Problems of Forensic Sciences 62: 166-177.

Ćwiklińska, Monika, Grzegorz Teresiński, Grzegorz Buszewicz. 2015. „Medyczno-sądowe oraz prawno-karne aspekty opiniowania i orzekania w przypadkach intoksykacji środkami odurzającymi i działającymi podobnie do etanolu". Archiwum Medycyny Sądowej i Kryminologii 65 (2): 77-89.

Dąbrowska-Kardas, Małgorzata, Piotr Kardas. 1999. „Odpowiedzialność karna za spowodowanie wypadku komunikacyjnego w świetle regulacji nowego kodeksu karnego z 1997 r. Cz. II". Palestra 3-4: 35-51.

Dąbrowski, Jacek. 2009. „Glosa do uchwały Sądu Najwyższego z dnia 27 lutego 2007 r., sygn. akt I KZP 36/06". Wojskowy Przegląd Prawniczy 2: 128-133.

Engelgardt, Piotr, Ewa Pufal, Karol Śliwka. 2006. "Evaluation of preliminary medical examination in the assessment of drugged drivers. Przydatność wstępnego badania lekarskiego w ocenie kierowców będących pod wpływem środków działających podobnie do alkoholu". Problems of Forensic Sciences 68: 368-377.

Girdwoyń, Piotr. 2012. „Stan nietrzeźwości i po użyciu alkoholu oraz innych środków psychoaktywnych - dopuszczalne analogie? Uwagi na tle art. 178a $\S 1$ i art. $87 \S 1$ kw". Wojskowy Przeglad Prawniczy 4. http://www.npw.gov.pl/dokumenty/WPP/2012-4/2012-4-18.pdf [dostęp 30.10.2015].

Hanausek, Tadeusz. 1974. „Glosa do uchwały Sądu Najwyższego z dnia 15 lutego 1973 r., VI KZP 78/72". Orzecznictwo Sąów Polskich 7-8: 351-354.

Hołda, Zbigniew. 1973. „Glosa do uchwały SN z 15 lutego 1973 r., VI KZP 78/72”. Problemy Praworzadności 10: 43-46.

Huminiak, Tomasz. 2004. „Stan «pod wpływem środków odurzających» i stan «po użyciu środka działającego podobnie do alkoholu» u kierującego pojazdem”. Paragraf na Drodze 3: 5-16.

Huminiak, Tomasz. 2005. „Pojęcia «środek działający podobnie do alkoholu» i «środek odurzający». Kolejne uwagi". Paragraf na Drodze 5: 5-15. 
Huminiak, Tomasz. 2007. „Glosa do uchwały Sądu Najwyższego z dnia 27 lutego 2007 r., sygn. akt I KZP 36/06, w sprawie pojęcia środka odurzającego". Paragraf na Drodze 6: 5-12.

Joachimiak, Sławomir. 2014 „Glosa do wyroku SN z dnia 4 października 2013 r., sygn. IV KK 136/13". Paragraf na Drodze 9: 18-23.

Kachel, Grzegorz. 2008 „Glosa do uchwały Sądu Najwyższego z dnia 27 lutego 2007 r., sygn. akt I KZP 36/06". Gdańskie Studia Prawnicze - Przeglad Orzecznictwa 2: 139-142.

Kała, Maria. 2004. „Środki działające podobnie do alkoholu w organizmie kierowcy”. Paragraf na Drodze 11: 41-68.

Kała, Maria, Piotr Adamowicz, Ewa Chudzikiewicz, Wojciech Lechowicz, Ewa Pufal, Marzena Sykutera, Wojciech Piekoszewski, Janusz Pach, Karol Śliwka. 2005. "Substances acting similarly to alcohol in the organism of drivers. Środki działające podobnie do alkoholu w organizmach kierowców". Problems of Forensic Sciences 62: 133-144.

Kochanowski, Maciej, Maria Kała. 2005. "Determination of tetrahydrocannabinols in saliva. Oznaczanie tetrahydrokannabinoli w ślinie". Problems of Forensic Sciences 62: 178-187.

Korczyńska, Małgorzata, Joanna Kulikowska, Rafał Celiński, Joanna Nowicka, Sebastian Rojek, Anna Uttecht-Pudełko. 2011. „Stan „pod wpływem substancji odurzających lub psychotropowych" - porównanie wyników badań toksykologicznych z oceną lekarską w materiałach Katedry i Zakładu Medycyny Sądowej i Toksykologii Sądowo-Lekarskiej Śląskiego Uniwersytetu Medycznego w Katowicach". Archiwum Medycyny Sadowej i Kryminologii 61: $35-42$.

Krajewski, Stefan. 2003. „Pojęcie środka odurzającego na gruncie kodeksu karnego”. Państwo i Prawo 11: 30-42.

Lechowicz, Wojciech, Vanessa Bunker. 2005. "Hair as a complementary material in drug testing of drivers for benzodiazepines. Włosy jako materiał komplementarny w badaniach kierowców na obecność w ich organizmach środków działających podobnie do narkotyków". Problems of Forensic Sciences 62: 157-165.

Łucarz, Katarzyna, Anna Muszyńska. 2008a. „Pojęcie środka odurzającego w prawie karnym”. Państwo i Prawo 6: 91-102.

Łucarz, Katarzyna, Anna Muszyńska. 2008b. „Glosa do uchwały Sądu Najwyższego z dnia 27 lutego 2007 r., sygn. akt I KZP 36/06”. Przegląd Sąowy 3: 122-130.

Małek, Roman. 2007. „Glosa do uchwały Sądu Najwyższego z dnia 27 lutego 2007 r., sygn. akt I KZP 36/06". Wojskowy Przeglad Prawniczy 4: 96-100.

Marcinkowski, Wojciech. 2002. „Zakresy ustawowych znamion niektórych przestępstw i wykroczeń komunikacyjnych”. Wojskowy Przeglad Prawniczy 1: 39-43.

Nowak, Paweł. 2013. „Wykładnia znamion «stan pod wpływem środka odurzającego» oraz «stan po użyciu środka działającego podobnie do alkoholu» w świetle konstytucyjnego wzorca kontroli”. Paragraf na Drodze 1: 11-34.

Olszewski, Artur Tomasz. 2008. „Glosa do uchwały Sądu Najwyższego z dnia 27 lutego 2007 r., sygn. akt I KZP 36/06”. Prokuratura i Prawo 12: 154-159.

Paprzycki, Lech K. 2012. „Stan po użyciu i stan pod wpływem środka odurzającego”. Paragraf na Drodze 1: 25-29.

Pawlik, Renata. 2013. „Społeczna szkodliwość czynu - wybrane zagadnienia na przykładzie wykroczenia typizowanego w art. 87 KW". Kwartalnik Krajowej Szkoły Sadownictwa i Prokuratury 10 (4): $38-54$.

Pawlik, Renata. 2014. „Znamię stanu pod wpływem środka odurzającego w świetle projektu nowelizacji Kodeksu karnego". Kwartalnik Krajowej Szkoły Sądownictwa i Prokuratury 13 (Zeszyt Specjalny): 46-65.

Redo, Sławomir. 1976 „Glosa do uchwały Sądu Najwyższego z dnia 15 lutego 1973 r., VI KZP 78/72”. Państwo i Prawo 5: 175-179. 
Rok-Błeszyńska, Magdalena. 2003. „Kierowca pod wpływem narkotyków a bezpieczeństwo w ruchu drogowym". Problemy Wspótczesnej Kryminalistyki 7 (1): 147-155.

Sabatowski, Sławomir. 2003. „Czy wolno jeździć pod wpływem LSD?”. Problemy Współczesnej Kryminalistyki 7 (1): 157-170.

Skowron, Andrzej. 2004. „Jeszcze raz krytycznie o środkach działających podobnie do alkoholu”. Paragraf na Drodze 11: 13-21.

Skowron, Andrzej. 2006. „O potrzebie zmian w określeniu znamion przestępstwa i wykroczenia związanych z używaniem środków działających podobnie do alkoholu". Paragraf na Drodze 2: $22-29$.

Skowron, Andrzej. 2007. „Jeszcze o problemie braku rozgraniczenia znamion «środek działający podobnie do alkoholu» $\mathrm{i}$ «środek odurzający» w kontekście badań laboratoryjnych materiału pobranego od kierowców". Paragraf na Drodze 11: 32-38.

Skowron, Andrzej. 2012a. „Problem powracający jak bumerang, czyli ponownie o środkach działających podobnie do alkoholu". Paragraf na Drodze 8: 5-12.

Skowron, Andrzej. 2012b. „Glosa do wyroku SN z dnia 7 lutego 2007 r., V KK 128/06”. Lex/el.

Skowron, Andrzej. 2012c. „Glosa do postanowienia SN z dnia 31 maja 2011 r., V KK 398/10”. Lex/ el.

Skowron, Andrzej. 2014a. „Problematyka «środków działających podobnie do alkoholu» - po raz «enty» (część 1)". Paragraf na Drodze 2: 25-31.

Skowron, Andrzej. 2014b. „Problematyka «środków działających podobnie do alkoholu» - po raz «enty» (część 2)". Paragraf na Drodze 3: 20-26.

Stefański, Ryszard A. 1999. „Prawna ocena stanów związanych z używaniem środków odurzających w ruchu drogowym". Prokuratura i Prawo 4: 18-24.

Stefański, Ryszard A. 2007. „Glosa do uchwały Sądu Najwyższego z dnia 27 lutego 2007 r., sygn. akt I KZP 36/06". Państwo i Prawo 8: 130-135.

Stefański, Ryszard A. 2008a. „Prawo o ruchu drogowym. Komentarz”. Warszawa: Wolters Kluwer.

Stefański, Ryszard A. 2008b. „Glosa do wyroku SN z dnia 7 lutego 2007 r., V KK 128/06”. Przegląd Sadowy 6: 152-158.

Stefański, Ryszard A. 2014, „Glosa do wyroku SN z dnia 4 października 2013 r., sygn. IV KK 136/13”. Orzecznictwo Sąów Polskich 5: 644-658.

Sybirska, Halina, Jerzy Szczepański, Joanna Kulikowska. 1999. „Substancje odurzające we krwi uczestników ruchu drogowego - doświadczenia Katedry i Zakładu Medycyny Sądowej Śląskiej Akademii Medycznej w Katowicach”. Problems of Forensic Sciences 39: 65-76.

Wachowiak, Roman. 2005. "Diagnostic and interpretation problems resulting from the presence of psychoactive compounds in a car driver body. Problemy diagnostyczno-interpretacyjne wynikające z obecności związków psychoaktywnych w organizmach kierowców pojazdów samochodowych". Problems of Forensic Sciences 57: 145- 156.

Wachowiak, Roman, 2008. "Aktualne możliwości diagnostyczno-interpretacyjne w opiniowaniu sądowo-lekarskim wpływu wybranych związków psychoaktywnych na zdolność psychomotoryczną człowieka”. Prokuratura Okręgowa w Zielonej Górze. http://www.zielona-gora.po.gov. pl/magazyn/upload/lektury_elektroniczne/zabezpieczenie-materialu-do-badan-zielona-gora4. pdf [dostęp 30.10.2015].

Wiergowski, Marek, Zbigniew Jankowski, Ewa Tomczak, Jacek Sein Anand, Rafał Ziółkowski, Janusz Staniszewski. 2012. „Propozycja testów oceniających zdolności psychomotoryczne kierowcy oraz protokołu do zastosowania w trakcie pobrania i badania śliny, krwi oraz moczu w przypadku podejrzenia przyjęcia środków działających podobnie do alkoholu". Archiwum Medycyny Sadowej i Kryminologii 62 (3): 186-197.

Wojtanowska, Katarzyna. 2008. „Glosa do uchwały Sądu Najwyższego z dnia 27 lutego 2007 r., sygn. akt I KZP 36/06”. Prokuratura i Prawo 12: 141-153. 
Wolski, Stanisław, Ewa Lewandowska, Małgorzata Kurzejemska-Parafiniuk. 2013. „Przydatność wstępnego badania lekarskiego w sprawach dotyczących podejrzanych o kierowanie pojazdami pod wpływem amfetaminy i jej analogów lub $\Delta^{9}$-tetrahydrokannabiolu na podstawie materiałów Katedry Medycyny Sądowej Pomorskiego Uniwersytetu Medycznego w Szczecinie". Annales Academiae Medicae Stetinesis. Roczniki Pomorskiej Akademii Medycznej w Szczecinie 2: 147-156.

\title{
Magdalena Mazurek-Wardak, Zbigniew Wardak
}

\section{COMMENTARY ON THE SENTENCE OF THE SUPREME COURT - DECEMBER 3, 2014, REF. NO. II KK 219/14}

\begin{abstract}
The article is an approving gloss on the resolution of the Supreme Court of December 3, 2014, Ref. No. II KK 219/14. The article particularly focuses on the need arising from this decision to establish the real impact of an intoxicant on a driver's psychomotor performance in the event of their committing a crime against the traffic safety under the influence of this intoxicant. The authors propose using tests assessing psychomotor impairment in drivers suspected of using substances acting similarly to alcohol.
\end{abstract}

Keywords: intoxicants, substance acting similarly to alcohol, psychomotor capacity, narcotests. 